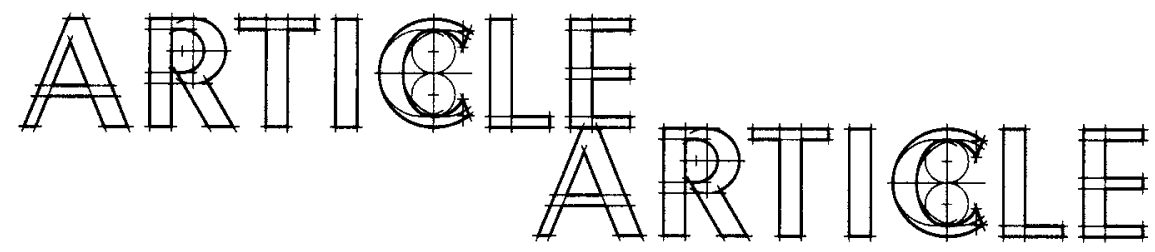

\title{
Canadians receive distinctions at the AAO meeting in Denver, Colorado
}

Members from the two Canadian schools of optometry participated at the American Academy of Optometry (AAO) annual meeting held for the last time in December in Denver, Colorado. Next year will be the first time the AAO annual meeting will be held in October. Several Canadian members were honored at the annual awards as well.

\section{ÉCOLE D'OPTOMÉTRIE, UNIVERSITÉ DE MONTRÉAL, MONTRÉAL, QUÉBEC}

\section{A. Participation}

\begin{tabular}{|c|c|c|}
\hline Bitton E. & A closer look at the tear film & conférence (1hr) \\
\hline $\begin{array}{l}\text { Bitton } E \text {, Keech A, } \\
\text { Simpson T, Jones L }\end{array}$ & $\begin{array}{l}\text { Inter and intra-observer variability in tear } \\
\text { meniscus determined using OCT }\end{array}$ & poster \\
\hline $\begin{array}{l}\text { Bitton } E \text {, Keech A, } \\
\text { Jones L, Simpson T }\end{array}$ & Overnight variation in tear ferning & poster \\
\hline Corbeil M-E, Faubert J & $\begin{array}{l}\text { Perception of first-and-second order stimuli } \\
\text { in humans after early visual deprivation }\end{array}$ & poster \\
\hline $\begin{array}{l}\text { Diaconu V, Vucea V, } \\
\text { Frenette B }\end{array}$ & $\begin{array}{l}\text { Optical fournier transform to evaluate } \\
\text { surface quality of ophthalmic lenses }\end{array}$ & poster \\
\hline $\begin{array}{l}\text { Frenette B, Citek K, } \\
\text { Fontaine N, } \\
\text { Larocque AM }\end{array}$ & $\begin{array}{l}\text { Comparitive study of physical and } \\
\text { mechanical properties of last generation } \\
\text { anti-reflect treatments }\end{array}$ & poster \\
\hline $\begin{array}{l}\text { Giasson C, Djouahra S, } \\
\text { Sauvageau P, Danion A, } \\
\text { Vermette P }\end{array}$ & $\begin{array}{l}\text { Absorption spectra of soft contact lenses } \\
\text { with multilayers of liposomes as a model } \\
\text { for ophthalmic drug release }\end{array}$ & poster \\
\hline $\begin{array}{l}\text { Lovasik JV, Kergoat H, } \\
\text { Parent M }\end{array}$ & $\begin{array}{l}\text { Quantifying the foveal and perifoveal } \\
\text { choroidal blood flow and pulsatility index } \\
\text { for the human eye }\end{array}$ & poster \\
\hline $\begin{array}{l}\text { Selvin G, Hom M, } \\
\text { Michaud L, Huang S, } \\
\text { Edmondson W, Anderson M }\end{array}$ & $\begin{array}{l}\text { Grand Rounds :Cornea and Anterior } \\
\text { Segment }\end{array}$ & conférence ( $2 \mathrm{hrs}$ ) \\
\hline Michaud L, Marinier JA & $\begin{array}{l}\text { Intacs as a low-vision treatment for a } \\
\text { keratoconic patient with down syndrome }\end{array}$ & poster \\
\hline $\begin{array}{l}\text { Dubuc S, Wittich W, } \\
\text { Overbury O, Kapusta M }\end{array}$ & $\begin{array}{l}\text { What charts results convey \& what patients } \\
\text { subjectively report: the same or different? }\end{array}$ & poster \\
\hline $\begin{array}{l}\text { Allard R, Carcenac G, } \\
\text { Faubert J. }\end{array}$ & $\begin{array}{l}\text { Aging and the sensitivity loss to complex } \\
\text { stimuli }\end{array}$ & paper \\
\hline Total : Poster : 9 & Conferences : 2 & \\
\hline
\end{tabular}

\section{A. Distinction}

Student Travel Grants: Judith Renaud (Low Vision Student travel Fellowship); Remy Allard (Canadian Student Travel Fellowships, Vistakon); Sara Dubuc (Vistakon educational grant). 
SCHOOL OF OPTOMETRY, UNIVERSITY OF WATERLOO, WATERLOO, ONTARIO

A. Participation

Hildebrand J, Spafford M,

Schryer F, Lingard

Spafford M M, Schryer F, Lingard,

Hildebrand $M$

Spafford, M M, Laliberte R, Leipert D,

Klinger, Huot

Suryakumar R, Chan, Irving L, Bobier R

Hovis J K, Robertson, Chou

Babu R J, Leat J, Irving L

Rose P A, Hudson

Venkataraman S T, Hudson, Fisher A, Rachmiel, Buys, Trope E, Flanagan G

Flanagan J G, Chauhan, Quigley A

Schulze M M, Simpson L, Hutchings

Jones $\mathrm{D}$, Woods $\mathrm{A}$, Jones $\mathrm{W}$,

Morgan B

Chou B R, Suwala, Hovis K

Cooper S, Hrynchak K

Duench S, Sorbara, Simpson L, Jones W, Fonn

Woods C A, Dumbleton, German,

Dong, Fonn

Dumbleton K A, Woods A, Jones W,

Feng, Moezzi M, Fonn

Dumbleton K A, Jones W, Woods A,

Feng, Moezzi M, Fonn

Shinde L, Cronje, Jayanna,

Sweeney F, Fonn

Woods C A, Roy, Fonn

Woods C A, Tsang, Fonn

Woods J, Woods A, Varikooty,

Jones W, Simpson L, Fonn

Keir N J, Situ, Richter,

Jones W, Fonn
Learning how to write optometry referral letters: situated

Poster opportunities and constraints

Where's the Patient? Patient-centered talk in referral and consultant Poster letters

When the time is right: Reasons why older adults with low vision are Poster without low vision services

Photorefractive assessment of the dynamic differences between Paper accommodation and disaccommodation

Laboratory studies of constant and variable thickness visors Poster

Looming: Effects of speed and target location Poster

Age related changes in retinal arteriolar and venular blood flow and Poster reactivity in clinically healthy subjects

Retinal arteriolar vascular reactivity in response to isoxic hypercapnia Poster in primary open angle glaucoma pre \& post treatment - Preliminary results

Truths, Half Truths and Lesser Truths: A Practical Guide to the Recent Conf. Clinical Trials in Glaucoma

The accuracy of grading scales for bulbar redness

Paper

The use of silicone hydrogel contaact lenses by Canadian Poster optometrists: 2000-2006

Effect of Nike Maxsight contact lenses on traffic signal visibility Paper

Results of the Canadian Bridging Program for internationally trained Poster optometrists

The use of fluorophotometry to measure corneal epithelial permeability to contact lenses and contact lens care regimens

Poster

The assessment of contact lens symptomology using wireless Paper handheld communication devices

Comfort and adaptation to silicone hydrogel lenses for daily wear Paper

Clinical performance of a hydrogel peroxide care regimen with silicone hydogel lenses

IACLE's role in improving contact lens education in India:

Poster a case study

Radial power profiles of single vision silicone hydrogel lenses

Poster

Comparing gravimetric and refractive methods of measuring water Poster content for various soft lenses

A novel method of recording corneal staining that facilitates

Poster parametric analysis

Clinical performance of alexidine-based and polyquad-based multi- Poster purpose solutions when used with daily wear Etafilcon lenses 


\section{ARTICLE ARTICLE}

\begin{tabular}{|c|c|c|}
\hline Moezzi A M, Fonn, Simpson L & $\begin{array}{l}\text { Comparison of overnight corneal swelling induced by prototype } \\
\text { Lotrafilcon A Toric versus Balafilcon A Toric }\end{array}$ & Paper \\
\hline $\begin{array}{l}\text { Keir N J, Dumbleton A, } \\
\text { Jones W, Fonn D }\end{array}$ & $\begin{array}{l}\text { A 12-mo. clinical comparison of continuous wear surface modified } \\
\text { and non-surface modified silicone hydrogel contact lens materials }\end{array}$ & Paper \\
\hline $\begin{array}{l}\text { Srinivasan S, Varikooty, Subbaraman N, } \\
\text { Chan, Woods, Simpson, Jones, Fonn }\end{array}$ & $\begin{array}{l}\text { Atypical manifestation of upper lid margin staining in silicone } \\
\text { hydrogel lens wearers with symptoms of dry eye }\end{array}$ & Poster \\
\hline $\begin{array}{l}\text { Varikooty J, Srinivasan S, Subbaraman, } \\
\text { Chan, Woods, Jones, Simpson L, Fonn }\end{array}$ & $\begin{array}{l}\text { Clinical manifestations of upper lid staining in adapted silicone } \\
\text { hydrogel lens wearers }\end{array}$ & Poster \\
\hline $\begin{array}{l}\text { Varikooty J, Srinivasan, Subbaraman N, } \\
\text { Feng, Jones W, Simpson L, Fonn }\end{array}$ & $\begin{array}{l}\text { The influence of pre-soaking single-use Etafilcon contact lenses on } \\
\text { ocular comfort in symptomatic \& asymptomatic contact lens wearers }\end{array}$ & Poster \\
\hline $\begin{array}{l}\text { Keir N J, Dumbleton, Woods A, Jones, } \\
\text { Simpson L, Fonn, Cohen R, Potter B }\end{array}$ & $\begin{array}{l}\text { The influence of a lubricant eye drop on ocular discomfort in } \\
\text { symptomatic hydrogel contact lens wearers }\end{array}$ & Poster \\
\hline Bitton E, Keech, Simpson L, Jones W & Inter \& intra observer variability in tear meniscus determined using OCT & Poster \\
\hline $\begin{array}{l}\text { Srinivasan S, Jones, Joyce, Simpson L, } \\
\text { Senchyna }\end{array}$ & $\begin{array}{l}\text { Characterization of clinical signs and symptoms in asymptomatic and } \\
\text { symptomatic dry eyed postmenopausal women }\end{array}$ & Poster \\
\hline Jones L, Dumbleton & Specialty Applications of Silicone Hydrogel Contact Lenses & Conf. \\
\hline Luensmann D, Glasier, Zhang, Jones W & $\begin{array}{l}\text { A novel in vitro method to determine the penetration profile of } \\
\text { albumin into silicone hydrogel and conventional hydrogel contact } \\
\text { lens materials }\end{array}$ & Paper \\
\hline Bitton E, Keech, Jones W & Overnight variation in tear ferning & Poster \\
\hline $\begin{array}{l}\text { Suwala M, Glasier, Subbaraman N, } \\
\text { Jones }\end{array}$ & $\begin{array}{l}\text { Quantity and conformation of Lysozme deposited on conventional } \\
\text { and silicone hydrogel contact lens materials using an in vitro model }\end{array}$ & Poster \\
\hline Dalton K N, Rogers, Jones W & $\begin{array}{l}\text { Osmolality, PH, viscosity and surface tension of multi-purpose } \\
\text { contact lens solutions }\end{array}$ & Poster \\
\hline Srinivasan S, Joyce, Jones, Senchyna & $\begin{array}{l}\text { Tear osmolality and ferning patterns in postmenopausal women with } \\
\text { and without symptoms of dry eye }\end{array}$ & Paper \\
\hline $\begin{array}{l}\text { Subbaraman L N, Glasier, Senchyna, } \\
\text { Sheardown, Jones W }\end{array}$ & $\begin{array}{l}\text { Lysozyme uptake kinetics on PMMA, FDA groups I, II, IV and first \& } \\
\text { second generation silicone hydrogel contact lens materials }\end{array}$ & Poster \\
\hline $\begin{array}{l}\text { Subbaraman L N, Jones W, Srinivasan, } \\
\text { Varikooty, Glasier }\end{array}$ & $\begin{array}{l}\text { Activity of lysozyme deposited on one-day etafilcon contact lenses is } \\
\text { correlated with subjective comfort }\end{array}$ & Paper \\
\hline Total : Poster : 25 & Conferences : 2 & \\
\hline
\end{tabular}

\section{B. New Fellows (FAAO)}

Lakshman N Subbaraman; Subha Trichy Venkataraman; Dr Rajaraman Suryakumar

\section{Distinctions/Awards}

Student Travel Grants: Adam Keech (Vistakon educational grant); Sruthi Srinivasan (Canadian Student Travel Fellowships, Vistakon); Lakshman Subbaraman (Canadian Student Travel Fellowships, Vistakon); Doerte Luensmann (Vistakon educational grant); Marc Schulze (Vistakon educational grant); Raiju J Babu (AAO travel grant); Jenna M Hildebrand (AAO travel grant); Subha T Venkataraman (AAO travel grant)

\section{Michael G. Harris Family Award for Excellence in Optometric Education:}

Awarded to Dr. Lyndon Jones, PhD, FCOptom, FAAO

"This award is presented by the American Optometric Foundation (AOF) to an optometric educator who bas demonstrated ongoing and consistent excellence in the education of optometry students and/ or the advancement of optometric education. » 